\title{
STUDIES ON NATURAL IMMUNITY TO PNEUMOCOCCUS
} TYPE III

\author{
IV. Observations on a Non-Type Specific Humoral Factor \\ Involved in Resistance to Pneumococcus Type III \\ By JOHN F. ENDERS, PH.D., CHAO-JEN WU, ${ }^{*}$ M.D., AND \\ MORRIS F. SHAFFER,* PH.D. \\ (From the Department of Bacteriology and Immunology, The Harvard \\ Medical School, Boston)
}

(Received for publication, May 11, 1936)

Experimental evidence presented in Paper III $^{1}$ indicates that removal and destruction of both rabbit virulent and avirulent strains of Pneumococcus Type III in the normal animal are brought about by the same means, namely, the phagocytic cells of the body, provided the integrity of the capsule becomes impaired. It leaves unanswered, however, the interesting question as to whether this phagocytosis is "spontaneous," that is, taking place without the intervention of a serum component, or whether the adjuvant action of an antibody is essential to the process. The following experiments although they fail to give a complete answer do nevertheless reveal the participation of an antibody reacting with the somatic $\mathrm{C}$ carbohydrate of Tillett, Goebel and Avery (1) which not only appears to play a rôle in the phagocytosis of normal animals but is probably responsible for bringing about the non-type specific immunity which Tillett (2) obtained in rabbits vaccinated with $R$ pneumococcus or the smooth form of a heterologous type.

\section{Methods and Materials}

The strains of Pneumococcus Type III and the $R$ variants derived from them were the same as those mentioned in Paper $\mathrm{I}^{2}$

* At the time this work was done, Dr. Wu held a Travelling Fellowship from the Peiping Union Medical School, and Dr. Shaffer a Fellowship in the Medical Sciences from the National Research Council.

${ }^{1}$ Enders, J. F., Shaffer, M. F., and Wu, C.-J., J. Exp. Med., 1936, 64, 306.

${ }^{2}$ Enders, J. F., and Shaffer, M. F., J. Exp. Med., 1936, 64, 7. 
The $\mathrm{C}$ carbohydrate of the pneumococcus was prepared according to the procedure of Tillett, Goebel and Avery from an $\mathrm{R}$ variant obtained from our stock strain of Pneumococcus Typje I.

The soluble specific substance was prepared from cultures of strain $\mathrm{CH}$ according to the procedure of Heidelberger, Goebel and Avery (3).

Anti-R pneumococcus serum was produced in rabbits according to the method described in Paper I.

References to the techniques used in the phagocytic work have been noted in Papers II $^{3}$ and III.

Effect of C Carbohydrate on the Phagocytosis of Pneumococcus Type III by Normal Cells and Serum

The antiphagocytic effect of the type specific carbohydrate in systems containing the homologous antibody has been demonstrated by such studies as those of Sia (4) and Ward and Enders (5). This antibody, however, appears to be entirely absent in the normal rabbit as indicated by the work of Tillett (6), and the observations recorded below concerning the effect of the type specific carbohydrate on the phagocytosis of Type III pneumococcus in the rabbit system. We were induced, therefore, to make a further study of the antibody reacting with another known antigenic constituent of this organism, namely, the $\mathrm{C}$ carbohydrate or species specific polysaccharide of Tillett, Goebel and Avery. Particular attention was directed to this fraction and its antibody, since the failure of Tillett to produce any evidence of increased resistance after injection of pneumococcus nucleoprotein would seem to eliminate the homologous antibody from any participation in the natural immunity of the rabbit or that which ensues when intact $R$ forms or heterologous $S$ strains are employed as vaccines.

In Table $\mathrm{I}$, the effect of adding 1 drop of the $\mathrm{C}$ carbohydrate on the phagocytosis of old cultures of strain SV in $0.25 \mathrm{cc}$. of a suspension of the leucocytes and serum of a normal rabbit is shown. The number of organisms from a 22 hour culture taken up by the cells in the absence of $\mathrm{C}$ is reduced about 33 per cent when this substance in a dilution of $1: 200$ is added. A concentration of 1:1,000 exhibits no depressive action on them, but does influence the ingestion of the 30 hour cultures. In another experiment, when a culture much younger than these (10 hour SV and $\mathrm{CH}$ ) was used, the effect of the addition of the $\mathrm{C}$ carbohydrate was

${ }^{3}$ Shaffer, M. F., Enders, J. F., and Wu, C.-J., J. Exp. Med., 1936, 64, 281. 
even more pronounced. The introduction of the type specific carbohydrate does not reduce the phagocytosis compared with the control of normal serum only. In the lower half of the table are included figures obtained from an experiment in which the $\mathrm{C}$ carbohydrate was added to normal human defibrinated blood. Here, its effect is very pronounced when the strain used is SV. With $\mathrm{CH}$, its action though definite is less marked. In other experiments of the same kind, smaller

\section{TABLE I}

Effect of C Carbohydrate on the Phagocytosis of Pneumococcus Type III by the Normal Serum and Polymorphonuclear Leucocytes of Man and the Rabbit

\begin{tabular}{|c|c|c|c|c|c|c|c|}
\hline Strain & $\begin{array}{l}\text { Age of } \\
\text { culture }\end{array}$ & Material tested & $\begin{array}{l}\text { Average } \\
\text { No. of } \\
\text { cocci per }\end{array}$ & $\begin{array}{c}\text { Cells } \\
\text { containing }\end{array}$ & \multicolumn{3}{|c|}{ No, cells counted } \\
\hline & krs. & & & per cent & & & \\
\hline SV & 22 & - & 11.2 & 29.0 & $300)$ & & \\
\hline SV & 22 & C 1:200 & 7.5 & 24.2 & 264 & & \\
\hline SV & 22 & C $1: 1,000$ & 13.3 & 40.0 & 200 & & \\
\hline SV & 22 & SSS III $1: 1,000$ & 12.3 & 33.0 & 200 & & \\
\hline SV & 30 & - & 15.4 & 43.0 & 210 & & \\
\hline SV & 30 & C 1:200 & 10.0 & 33.0 & 200 & Normai & rabolt \\
\hline SV & 30 & C 1:1,000 & 10.8 & 27.0 & 150 & Cens & \\
\hline SV & 30 & SSS III $1: 1,000$ & 14.9 & 40.0 & 200 & & \\
\hline *SV & 10 & - & 18.4 & 32.4 & 250 & & \\
\hline SV & 10 & C 1:200 & 5.4 & 11.6 & 500 & & \\
\hline${ }^{*} \mathrm{CH}$ & 10 & - & 37.1 & 50.8 & 250 & & \\
\hline $\mathrm{CH}$ & 10 & C 1:200 & 17.1 & 32.4 & 250) & & \\
\hline SV & 18 & - & 61.0 & 94.0 & 50) & & \\
\hline SV & 18 & C 1:100 & 0.2 & 2.0 & 50 & & \\
\hline SV & 18 & SSS III 1:100 & 0.0 & 0.0 & 50 & ormai & numan \\
\hline $\mathrm{CH}$ & 18 & - & 221.6 & 100.0 & 50 & & \\
\hline $\mathrm{CH}$ & 18 & C $1: 100$ & 141.2 & 94.0 & 50 & & \\
\hline $\mathrm{CH}$ & 18 & SSS III 1: 100 & 32.2 & 58.0 & 50 & & \\
\hline
\end{tabular}

* The data on the 10 hour cultures of $\mathrm{CH}$ and SV were obtained in another experiment, employing the cells and serum of a different rabbit.

quantities of the material have been employed. These depress the phagocytosis of strain SV of this age in dilutions as high as $1: 10,000$ to $1: 100,000$. Little or no reduction in the numbers of strain $\mathrm{CH}$ ingested was brought about by these quantities. It is evident from the data that the type specific carbohydrate also has a similar action, reducing the numbers of strain SV ingested to zero and those of strain $\mathrm{CH}$ about seven times. To us this appears to denote that in the particular human blood used, both type specific and anti- $\mathrm{C}$ antibody were present. 
To opsonize this 18 hour culture of SV with its greater quantity of capsular material, the combined concentrations of both antibodies were necessary. The available amount of either one was by itself insufficient to bring this about. Since in the $\mathrm{CH}$ organism of this age the loss of capsular constituents is relatively much greater, opsonization may be accomplished by the concentration of the single antibody which remains after the elimination of the other by addition of its homologous antigen. Indeed, from information derived from unrecorded experiments it is probable that certain $\mathrm{CH}$ cocci have become at this stage of cultivation so susceptible to the attack of phagocytes that they can be ingested in the absence of sensitization by either the anti-SSS III or anti-C, or anti-P antibodies, since the addition of all these fractions together fails to remove entirely the phagocytic capacity of the system. Such organisms behave like the $\mathrm{R}$ variant, for we have found that the addition of these three known antigens of the pneumococcus has practically no effect on the phagocytosis of $R$ forms by the cells and serum of normal rabbits. These facts we consider may also serve to explain the residual phagocytosis seen after addition of the $\mathrm{C}$ carbohydrate to the rabbit system containing 22 hour cultures of strain SV. It is entirely possible that the cocci found within cells under these conditions represent forms so far degraded in respect to the antigenic properties of the surface that the anti-C antibody is not necessary for their opsonization. To eliminate the possibility that the action of the $\mathrm{C}$ carbohydrate consisted in fixation of complement, rather than in union with and neutralization of an opsonin of the serum, the titre of hemolytic complement in the system was determined. No diminution of complement ensued upon the addition of the $\mathrm{C}$ substance in the quantities employed.

On the basis of these results, it can be stated that an antibody or antibody-like principle in the normal sera of rabbit and man reacting with the $\mathrm{C}$ carbohydrate of the pneumococcus has a share in the opsonization of both rabbit virulent and avirulent smooth strains of Pneumococcus III, provided the capsule has become impaired, for it will be recalled from the data presented in Papers II and III that when young and fully capsulated, both these organisms are completely resistant to phagocytosis in human and rabbit systems.

\section{The Opsonic Property of Anti-R Pneumococcus Serum}

The fact that an antibody reacting with the $\mathrm{C}$ carbohydrate in normal serum contributed to the opsonization of the pneumococcus, together with the demonstration by Tillett of active and passive immunity in rabbits following injection of $R$ vaccine or anti- $R$ blood or serum, led us to determine whether or not a serum prepared in rabbits 
following prolonged treatment with heat-killed $\mathbf{R}$ pneumococci could increase the phagocytosis of strains $\mathrm{CH}$ and SV.

The usual technique was modified in the instances where the $\mathbf{R}$ serum was tested by mixing equal volumes of this serum and fresh normal rabbit serum. This mixture was added to the exudative leucocytes and the red cells which had been previously removed from the normal serum. In this way the antiserum

TABLE II

The Opsonic Effect of Anti-R Pneumococcus Serum on the Phagocytosis of Pneumococcus Type III by Rabbit Leucocytes

\begin{tabular}{|c|c|c|c|c|c|}
\hline Strain & $\begin{array}{l}\text { Age of } \\
\text { culture }\end{array}$ & Constituents of the system & $\begin{array}{c}\text { Average } \\
\text { No. of } \\
\text { cocci per } \\
10 \text { cells }\end{array}$ & $\begin{array}{c}\text { Cells } \\
\text { containing } \\
\text { cocci }\end{array}$ & $\begin{array}{l}\text { No. cells } \\
\text { counted }\end{array}$ \\
\hline & hrs. & & & per cent & \\
\hline $\mathrm{CH}$ & 6 & Normal serum & 5.1 & 9.0 & 200 \\
\hline $\mathrm{CH}$ & 6 & Normal serum + anti- $R$ serum & 10.2 & 17.0 & 200 \\
\hline $\mathrm{CH}$ & 6 & $\begin{array}{l}\text { Normal serum }+ \text { anti- } R \text { serum } \\
\quad+C 1: 1,000\end{array}$ & 1.7 & 3.0 & 200 \\
\hline $\mathrm{CH}$ & 16 & Normal serum & 87.0 & 86.0 & 50 \\
\hline $\mathrm{CH}$ & 16 & Normal serum + anti- $R$ serum & 128.0 & 96.0 & 50 \\
\hline $\mathrm{CH}$ & 16 & $\begin{array}{l}\text { Normal serum }+ \text { anti- } R \text { serum } \\
\quad+C 1: 1,000\end{array}$ & 69.3 & 79.0 & 100 \\
\hline SV & 16 & Normal serum & 7.6 & 18.5 & 400 \\
\hline SV & 16 & Normal serum + anti- $\mathrm{R}$ serum & 15.2 & 34.0 & 400 \\
\hline SV & 16 & $\begin{array}{l}\text { Normal serum }+ \text { anti-R serum } \\
\quad+C 1: 1,000\end{array}$ & 5.1 & 15.0 & 400 \\
\hline $\mathrm{CH}-\mathrm{R}$ & 6 & Normal serum & 385.0 & 100.0 & 10 \\
\hline CH-R & 6 & Normal serum + anti- $R$ serum & 338.0 & 100.0 & 10 \\
\hline $\mathrm{CH}-\mathrm{R}$ & 6 & $\begin{array}{l}\text { Normal serum }+ \text { anti-R serum } \\
\quad+C 1: 1,000\end{array}$ & 250.0 & 100.0 & 10 \\
\hline SV-R & 6 & Normal serum & 108.8 & 84.0 & 25 \\
\hline SV-R & 6 & Normal serum + anti- $\mathrm{R}$ serum & 158.8 & 96.0 & 25 \\
\hline SV-R & 6 & $\begin{array}{l}\text { Normal serum + anti- } R \text { serum } \\
\quad+C 1: 1,000\end{array}$ & 140.0 & 97.0 & 30 \\
\hline
\end{tabular}

could be obtained in sufficient concentration to be effective. From the data assembled in Table II, it will be seen that in the presence of anti-R serum the phagocytosis of a 6 hour culture of $\mathrm{CH}$ is increased 100 per cent, that of a 16 hour culture about 47 per cent. The number of 16 hour SV organisms ingested is also increased by 100 per cent. Addition of 1 drop of $1: 1,000$ dilution of the $C$ carbohydrate to the mixtures containing the $\mathrm{R}$ serum reduces the number of organisms phagocyted to a figure which is less than that of the normal serum. The reduction 
is particularly marked in the case of the 6 hour $\mathrm{CH}$ culture. Here, as with strain $\mathrm{SV}$ in the normal human serum, the greater effect of this substance on the younger cultures may, in part, depend upon the amount of surface antigen in relation to the quantity of available antibody. In the older culture, antigen is reduced and the small amount of antibody which may remain unbound after introduction of the $\mathrm{C}$ carbohydrate may be still sufficient for sensitization of a considerable number of organisms. Moreover, in older cultures, completely degraded forms not requiring the $\mathrm{C}$ antibody for opsonization have doubtless developed. Had greater concentrations of $\mathrm{C}$ carbohydrate been employed in this experiment, the results might have been even more striking.

To obtain information concerning the influence of the anti-R serum on $R$ forms of these strains the same type of experiment was done using 6 hour cultures of the $R$ variants derived from each. It is evident that the serum has no effect on the phagocytosis of that obtained from strain $\mathrm{CH}$. There is possibly some enhancement of the phagocytosis of strain SV-R, but because of the extremely large number of intracellular organisms present in all cases, and the small number of cells counted, no conclusive evidence is afforded of any definite action on the $R$ organisms of this antibody. It is certain that extensive ingestion of these forms may occur in its absence.

Taken as a whole, these experiments indicate that the anti-C antibody present in the serum of rabbits immunized with $R$ vaccine can increase the phagocytosis of the rabbit virulent and avirulent pneumococci, provided these be obtained from cultures in which the capsules of the organisms are no longer intact.

\section{The Protective Action in Mice of Anti-R Pneumococcus Rabbit Serum}

The previous experiments, since they revealed a certain amount of opsonic activity attributable to the anti-C carbohydrate antibody, induced us to ascertain whether or not this entity could in the animal body act in the capacity of a protective agent.

To this end a series of mice were injected intraperitoneally with $0.5 \mathrm{cc}$. of anti- $R$ pneumococcus rabbit serum prepared by repeated injections of heat-killed $\mathbf{R}$ pneumococci, derived from a strain of Pneumococcus Type I, as noted in the section on technique. A second series of animals was given the same quantity of the same anti-R serum, from which the precipitin reacting with the $\mathrm{C}$ carbohydrate had been removed by repeated precipitations at the point at which maximum flocculation occurred. The original serum gave a positive ring test with a dilution of $1: 10,000$ of the carbohydrate. After absorption of precipitin, no reaction was obtained using this technique with dilutions of the carbohydrate ranging from 1:100 to $1: 100,000$ A third series of animals was injected with $0.5 \mathrm{cc}$. of the 
anti-R serum, which had been previously treated with fresh guinea pig kidney with the object of removing the Forssman antibody which has been shown by Powell and coworkers (7), to increase in rabbits the therapeutic action of type specific pneumococcus antibody. Before absorption, the anti-R pneumococcus serum hemolyzed sheep cells in a dilution of 1:800. After absorption it failed

TABLE III

The Protective Action in Mice of Anti-R Pneumococcus Sera against Pneumococcus Type III and the Effect of Absorbing Such Sera with C Carbohydrate and Guinea Pig Kidney

\begin{tabular}{|c|c|c|c|c|c|c|c|c|c|c|c|}
\hline & \multicolumn{2}{|c|}{$\begin{array}{l}\text { Group } 1 \\
0.5 \text { cc. } \\
\text { anti- } R \\
\text { rabbit } \\
\text { serum } \\
\text { intraperi- } \\
\text { toneally }\end{array}$} & \multicolumn{2}{|c|}{$\begin{array}{c}\text { Group } 2 \\
0.5 \text { cc. } \\
\text { anti-R } \\
\text { rabbit } \\
\text { serum } \\
\text { absorbed } \\
\text { with C } \\
\text { intraperi- } \\
\text { toneally }\end{array}$} & \multicolumn{2}{|c|}{$\begin{array}{l}\text { Group } 3 \\
0.5 \text { cc. } \\
\text { anti-R } \\
\text { rabbit } \\
\text { serum } \\
\text { absorbed } \\
\text { with guinea } \\
\text { pig kidney } \\
\text { intraperi- } \\
\text { toneally }\end{array}$} & \multicolumn{2}{|c|}{$\begin{array}{c}\text { Group } 4 \\
0.5 \text { cc. } \\
\text { normal } \\
\text { rabbit } \\
\text { serum } \\
\text { intraperi- } \\
\text { toneally }\end{array}$} & \multicolumn{2}{|c|}{$\begin{array}{c}\text { Group } 5 \\
\text { Untreated }\end{array}$} & \multirow[t]{2}{*}{ Remarks } \\
\hline & $\mathrm{s}$ & D & $\mathrm{s}$ & D & $\mathbf{S}$ & D & $s$ & D & $\mathbf{s}$ & D & \\
\hline Experiment 1 & 9 & 1 & 2 & 8 & nd & nd & 1 & 9 & nd & nd & $\begin{array}{l}\text { Groups } 1,2,4 \\
\text { received approx- } \\
\text { imately 5,800 } \mathrm{Pn} \\
\text { intravenously }\end{array}$ \\
\hline Experiment 2 & 5 & 5 & 0 & 11 & 7 & 3 & 4 & 7 & 1 & 3 & $\begin{array}{r}\text { Groups } 1,2,3,4 \\
\text { received approxi- } \\
\text { mately } 3,400 \\
\text { Pn intravenously. } \\
\text { Group } 5 \text { received } \\
\text { approximately } 34 \\
\text { Pn intravenously }\end{array}$ \\
\hline Totals. . & 14 & 6 & 2 & 19 & 7 & 3 & 5 & 16 & 1 & 3 & \\
\hline
\end{tabular}

All mice injected intravenously with $0.2 \mathrm{cc}$. of dilution of 6 hour broth culture of strain SV.

In the case of each mouse that died a culture of the heart's blood revealed the presence of pneumococcus.

to do so in a dilution of $1: 5$, - the lowest dilution tested. $0.5 \mathrm{cc}$. of normal rabbit serum was injected into a fourth series of mice. 24 hours later all the mice were injected intravenously with $0.2 \mathrm{cc}$. of a $10^{-4}$ dilution of a 6 hour broth culture of strain SV. Intravenous inoculation was employed since it was found that little or no protection was demonstrable when the culture was injected into the peritoneum. The results of two experiments, in only one of which, however, was the serum absorbed with guinea pig kidney employed, are summarized in Table III. Al- 
though the differences are not as sharp as one may obtain in protection tests with type specific sera and the intraperitoneal injection of the culture, they nevertheless seem sufficient to reveal a protective property in the anti- $R$ serum, which is greater than that shown by normal rabbit serum. The latter in Experiment 2 appears to have a slight action, since the percentage of untreated mice dying with a hundredfold-smaller inoculum exceeds that of those injected with normal rabbit serum ( $c f$. group 5 in Table III). Absorption of the anti-R serum with $\mathrm{C}$ carbohydrate, whether the result of a single experiment is considered, or the combined figures, is clearly associated with the removal of the protective property. Additional experiments of the same type not given here confirm this result. Elimination of the Forssman antibody apparently does not reduce the protection afforded by the $\mathbf{R}$ serum. Indeed, there is little reason to believe that it would do so, since the mouse tissues contain the antigen and would presumably remove the antibody before it might influence the pneumococcus. We included this control, however, to exclude any possible participation of the Forssman antibody in this non-type specific protection by anti-R serum.

Similar experiments have been undertaken using strain $\mathrm{CH}$. With this organism it was impossible to demonstrate any increase in resistance associated with the $\mathrm{R}$ serum. We attribute this failure to the fact that the normal mouse possesses a high degree of natural immunity against this strain when introduced intravenously. For testing the action of the $\mathbf{R}$ serum relatively enormous numbers of cocci must be introduced which in any case would probably overwhelm the majority of animals.

In general, we feel justified in concluding that anti-R pneumococcus rabbit serum containing antibody reacting with the $C$ carbohydrate will protect certain mice against 100 or more M.L.D. of strain SV when administered by the intravenous route. This protection disappears when the anti-C carbohydrate precipitin is removed by preliminary treatment with the homologous antigen, and therefore appears to be due to the action of that antibody.

\section{An Attempt to Actively Immunize Mice with $R$ Vaccine against Infection with Pneumococcus Type III}

Since antiserum produced in the rabbit in response to injection of $\mathbf{R}$ vaccine apparently conferred a certain degree of protection upon the mouse against virulent Pneumococcus III, provided the organisms were intravenously injected, experiments were undertaken with the object of determining whether or not active immunization of the mouse was possible following vaccination with suspensions of killed $R$ pneumococci. 
Twelve mice received three courses of intraperitoneal injections of $0.1 \mathrm{cc}$. of a suspension of 16 hour culture of $\mathrm{R}$ organisms resuspended in 0.3 per cent formalinized saline. Three injections on consecutive days were given in each course, followed by a rest of 5 to 7 days. To compare any resistance which might result from such vaccination with that obtained following injections of smooth Type III vaccine, the same number of animals were given the same course of immunization with a suspension in 0.3 per cent formalinized saline of twice the number of SV organisms centrifuged from a 6 hour broth culture. 10 days following the last course of vaccine, the animals were divided in groups of six each and inoculated intravenously with $0.2 \mathrm{cc}$. of dilutions of a 6 hour broth culture of strain SV. The results, together with those of unvaccinated controls, are recorded in Table IV. They obviously do not present definite evidence for the development of active immunity, following vaccination with the $R$ form. The survival of three mice out of the twelve injected with $R$ vaccine, and the death of all the nonvaccinated controls, although these received in some cases fewer pneumococci, are facts which

TABLE IV

Active Immunization of Mice, Using $R$ and $S$ Vaccines

\begin{tabular}{|c|c|c|c|c|c|c|c|c|c|c|c|c|}
\hline \multirow{3}{*}{$\begin{array}{l}\begin{array}{c}\text { No. pneumo- } \\
\text { cocci inocu- } \\
\text { lated........... }\end{array} \\
\text { Result.......... }\end{array}$} & \multicolumn{4}{|c|}{$\begin{array}{c}\text { Group } 1 \\
\text { Vaccinated with } \mathbf{R} \\
\text { pneumococcus }\end{array}$} & \multicolumn{4}{|c|}{$\begin{array}{c}\text { Group } 2 \\
\text { Vaccinated with S } \\
\text { Pneumococcus Type III }\end{array}$} & \multicolumn{4}{|c|}{$\begin{array}{c}\text { Group } 3 \\
\text { Non-vaccinated controls }\end{array}$} \\
\hline & \multicolumn{2}{|c|}{21,000} & \multicolumn{2}{|c|}{2,100} & \multicolumn{2}{|c|}{21,000} & \multicolumn{2}{|c|}{2,100} & \multicolumn{2}{|c|}{2,100} & \multicolumn{2}{|c|}{210} \\
\hline & $\mathbf{S}$ & D & $\mathbf{S}$ & D & $\mathbf{S}$ & D & S & D & $\mathbf{S}$ & D & $\mathbf{S}$ & D \\
\hline & 2 & 4 & 1 & 5 & 4 & 2 & 5 & 1 & 0 & 3 & 0 & 4 \\
\hline
\end{tabular}

suggest without proving that a slight resistance occurred after treatment with $R$ vaccine. The number of survivors in the groups prepared with $S$ vaccine is suffciently large to indicate definite protection which, however, is not by any means absolute. This fact, indicating as it does the difficulty with which active immunization of any kind against Pneumococcus Type III is obtained in the mouse, may serve to explain the doubtful immunity following injection of $R$ organisms which at best one could expect to be much less pronounced than that induced by the $S$ vaccine. It is possible that more prolonged immunization with the $R$ variant might reveal more definite evidence for the development of active immunity.

An Attempt to Eliminate the Natural Immunity of the Mouse to Strain $\mathrm{CH}$ by Injection of the C Carbohydrate

The protection conveyed to mice by the administration of anti- $R$ serum and the removal of the protective property upon the saturation of the serum with the $\mathrm{C}$ carbohydrate furnish a certain amount of 
information concerning the mechanism by which the rabbit virulent organisms may be resisted in the absence of the type specific antibody. We lack, however, complete data concerning the humoral factors which may participate in the removal by the normal animal of either this strain or the less virulent strain $\mathrm{CH}$, although the depression of phagocytosis in normal cells and serum by the $\mathrm{C}$ carbohydrate points to a participation of the corresponding antibody. Therefore, the attempt was made to reduce the resistance of the normal mouse to strain $\mathrm{CH}$ inoculated intravenously by an antecedent injection of the $\mathrm{C}$ carbohydrate with a view to reducing or removing in the animal any natural antibody which might react with it, since a similar procedure had been found effective in removing the immunity induced by previous vaccination with Pneumococcus Type I acetyl polysaccharide (Enders and Wu (8)).

Twenty mice were injected intraperitoneally with $0.5 \mathrm{cc}$. of $1: 500$ dilution of the $\mathrm{C}$ carbohydrate in physiological saline. Another lot was injected with the same quantity of saline as controls. 3 hours afterwards, the group receiving $\mathrm{C}$ carbohydrate was divided into four lots of five mice each. Each lot was injected with $0.2 \mathrm{cc}$. of broth dilutions of 6 hour cultures of strain $\mathrm{CH}$, falling from 1:100 to $1: 100,000$ by tenfold quantities. The controls were divided into lots of four each and injected with dilutions from $1: 10$ to $1: 100,000$ of the same culture. No significant differences were found in the number of deaths that occurred in lots receiving the same quantity of organisms, but one of which had been previously treated with the $\mathrm{C}$ carbohydrate.

This failure to demonstrate any depression of the resistance of the normal mouse to strain $\mathrm{CH}$ by preliminary injection of the $\mathrm{C}$ substance may be attributed either to the nonparticipation of the corresponding antibody in this protection, or to its incomplete removal by the amount of $\mathrm{C}$ carbohydrate administered. We are inclined to regard the last hypothesis as more plausible.

\section{DISCUSSION}

Although the $\mathrm{C}$ carbohydrate of the pneumococcus was isolated 6 years ago, little study has been devoted to its possible rôle in the mechanisms of immunity. It is known that this material forms a precipitate with its homologous antibody in vitro, and that its distribution among bacteria is apparently not limited to the pneumo- 
coccus alone, since cross reactions have been obtained, for example, with antimeningococcus serum. Furthermore, observations by Tillett and Francis (9), and by Finland and Dowling (10) show that when the $\mathrm{C}$ substance is injected intradermally into patients in the early stages of pneumonia an inflammatory reaction occurs. Subsequent to the time of crisis, the material fails to elicit this response. These facts suggest that an antibody reacting with the $C$ substance is present during the period of acute illness, but reveal nothing as to its function.

Before the discovery of the $\mathrm{C}$ carbohydrate, it was demonstrated that resistance in rabbits against virulent Type III pneumococci developed following the injection of vaccines consisting of $R$ organisms, or those of heterologous smooth types. Such resistance could be passively transferred to other rabbits with the blood or serum of those actively immunized. Tillett (2) believed that this protection did not depend upon the presence of the antipneumococcus protein antibody, or indeed upon the presence of any antibody, since his experiments showed that, whereas pure nucleoprotein (at that time the only species antigen recognized), or solutions of pneumococci, produced high titres of this antibody, but exhibited no protective power, the injection of intact $\mathrm{R}$ pneumococci or the smooth organisms of a heterologous type resulted in the appearance of protective properties in the serum.

The experiments described in this paper not only serve to suggest that the $\mathrm{C}$ carbohydrate and its corresponding antibody are involved in this non-type specific immunity against the pneumococcus, but, also, in fulfillment of their immediate objective afford an understanding of at least one of the humoral factors concerned in the defense of the normal animal against the two strains of Pneumococcus Type III, which are our particular concern. Specifically, they have shown that the $\mathrm{C}$ carbohydrate obtained from cultures of a rough variant of Pneumococcus Type I may inhibit the opsonic properties of the normal serum of man and the rabbit, which promote the phagocytosis of virulent Type III pneumococcus. Furthermore, it has been found that an antiserum prepared against the same $R$ variant of Pneumococcus Type I has a definite, though limited, opsonizing effect upon the smooth Type III organisms, which is abolished in the presence of a suitable quantity of the $\mathrm{C}$ carbohydrate. It is to be emphasized that the anti-C antibody whether present in normal or immune serum 
is effective in vitro as an opsonin only against organisms possessing imperfect capsules. Evidence that the antibody is active, not merely in the test tube, but also in the animal body is presented by experiments in which the anti- $R$ serum injected into one lot of mice apparently affords protection against a subsequent dose of the rabbit virulent Pneumococcus Type III provided these be inoculated by the intravenous route, while introduction of the same antiserum absorbed with the $\mathrm{C}$ carbohydrate fails to induce any increase in the resistance of the animals. The results of attempts to actively immunize mice against this strain by repeated injection of $R$ pneumococcus vaccine have proved inconclusive, but suggest that a slight depression of susceptibility to infection occurs in some animals. Injection of the $\mathrm{C}$ substance into normal mice previous to intravenous infection with the rabbit avirulent strain failed to reduce the high resistance of the animals. It also proved impossible by preliminary administration of the anti-R serum to increase the resistance of normal mice against $\mathrm{CH}$.

In spite of these failures, we believe that taken as a whole, the findings indicate that when the capsule of either strain has become slightly damaged, the anti-C antibody, which is present in normal animals in small amounts, may exert an opsonizing action which results in phagocytosis of the organisms, either by the leucocytes or the fixed tissue cells, as has been shown to occur ( $c f$. Paper III). Since alterations in the capsule of the rabbit avirulent strain have been demonstrated to take place more rapidly, and in a given time are more extensive, it is most probable that smaller quantities of this antibody are more effective against this strain than against the rabbit virulent strain, which maintains a large capsule for many hours. It is, however, also clear that in vitro capsular degradation may proceed to such an extent that sensitization with the anti-C antibody is not necessary as a preliminary step in the process of phagocytosis. During the natural course of infection this state is probably seldom attained, since before it is reached, opsonization by the anti-C antibody would have taken place with the resulting elimination of the organism.

If these findings prove to be correct and are found to have a more extensive application, one might possibly regard the anti-C carbohydrate antibody as an important factor in the natural immunity of individuals to infection not only with small doses of pneumococci, 
but with other organisms such as the meningococcus which possess, if not an identical, at least a similar antigenic constituent. Indeed, it does not appear illogical to think that this antibody may function successfully in protecting from infection those persons such as practically all infants, many young children and some adults, who have in their serum no naturally occurring antibody corresponding to the type specific antigen.

\section{CONCLUSIONS}

1. The phagocytosis of rabbit virulent and rabbit avirulent strains of Pneumococcus Type III by the cells and serum of both man and the normal rabbit is decreased by the previous addition of the $\mathrm{C}$ carbohydrate of Tillett, Goebel and Avery.

2. The addition of anti- $R$ pneumococcus serum to normal rabbit serum and cells results in increased phagocytosis of these strains, which is removed by the $\mathrm{C}$ carbohydrate.

3. Anti-R pneumococcus rabbit serum will protect mice against 100 or more M.L.D. of the rabbit virulent strain of Pneumococcus Type III, provided the organisms are injected by the intravenous route.

4. Absorption of anti-R pneumococcus rabbit serum with the $C$ carbohydrate removes the mouse protective property.

5. The application of these findings to the mechanism responsible for the removal of the rabbit virulent and avirulent strains from the circulating blood of the normal animal is discussed.

\section{SUMMARY AND GENERAL CONCLUSIONS}

Since there is no evidence for the occurrence of type specific antibody in the normal rabbit and since, as we have shown, the Pneumococcus Type III whether avirulent or virulent is not removed from the blood stream or destroyed when the capsule is intact, the following factors which have been revealed in the course of our work appear to represent certain essential components, if not the complete mechanism, upon which the natural immunity of the rabbit against this organism depends. (a) The elevation of the body temperature after intravenous infection to $41^{\circ} \mathrm{C}$. or thereabouts and its maintenance for varying periods. (b) The ability of the phagocytic cells, both fixed 
and mobile, to attack any cocci which have become vulnerable through the deterioration of capsular integrity. (c) The adjuvant effect of an antibody, reacting with the somatic $\mathrm{C}$ carbohydrate, which enhances the phagocytosis of such organisms as no longer possess a completely intact envelope.

Conversely, the varying degrees of virulence for rabbits observed among Pneumococcus Type III strains are based upon: (a) differences in the ability of the organisms to multiply at the elevated temperatures encountered in the infected host. Strains markedly susceptible to the harmful influence of this factor fail to induce a generalized fatal infection. Not all "thermo-resistant" strains are highly virulent, however, and these may contrast sharply with regard to $(b)$ size of the capsule and the ease with which it is impaired or completely lost. The capsules must be maintained intact for a sufficient time until multiplication of the organisms can proceed to such a degree that death of the host results. Avirulent strains even when capable of growth at $41^{\circ} \mathrm{C}$. appear to be unable to satisfy this requirement.

The differences in virulence of various strains apparently conditioned by these factors are not limited solely to the case of the rabbit, since for at least two strains similar differences in virulence have been shown to exist when the intravenous route of infection is employed in mice.

\section{BIBLIOGRAPHY}

1. Tillett, W. S., Goebel, W. F., and Avery, O. T., J. Exp. Med., 1930, 52, 895.

2. Tillett, W. S., J. Exp. Med., 1927, 46, 343.

3. Heidelberger, M., Goebel, W. F., and Avery, O. T., J. Exp. Med., 1925, 42, 727.

4. Sia, R. H. P., J. Exp. Med., 1926, 43, 633.

5. Ward, H. K., and Enders, J. F., J. Exp. Med., 1933, 57, 527.

6. Tillett, W. S., J. Exp. Med., 1927, 45, 1093.

7. Powell, H. M., Jamieson, W. A., Bailey, G. H., and Hyde, R. R., Am. J. Hyg., 1933, 17, 102.

8. Enders, J. F., and Wu, C.-J., J. Exp. Med., 1934, 60, 127.

9. Tillett, W. S., and Francis, T., Jr., J. Exp. Med., 1930, 52, 561.

10. Finland, M., and Dowling, H. F., J. Immunol., 1935, 29, 285. 